\title{
Role of Smac in cephalostatin-induced cell death
}

\author{
A Rudy ${ }^{1}$, N López-Antón ${ }^{1}$, N Barth ${ }^{1}$, GR Pettit ${ }^{2}$, VM Dirsch ${ }^{3}$, K Schulze-Osthoff ${ }^{4}$, M Rehm ${ }^{5}$, JHM Prehn ${ }^{5}$, M Vogler ${ }^{6}$, S Fulda ${ }^{6}$ and \\ AM Vollmar ${ }^{*, 1}$
}

\begin{abstract}
Cephalostatin 1 is a natural compound isolated from a marine worm that induces apoptosis in tumor cells via an apoptosomeindependent but caspase-9-dependent pathway and through an endoplasmic reticulum stress response that is accompanied by caspase-4 activation. Here, we show that cephalostatin evokes mitochondrial Smac (second mitochondria-derived activator of caspases) but not cytochrome $c$ release in various carcinoma cell lines. We also show that Smac is critically involved in caspase9 activation as evidenced by gene silencing experiments. Remarkably, caspase-2 appears to be a major target for cephalostatininduced cytosolic Smac. Using biochemical and genetic inhibition experiments, we demonstrate that caspase-2 participates in the apoptotic machinery induced by cephalostatin. Cephalostatin-activated caspase-2 appears to act as initiator caspase and is not involved in the activation of caspase-9. Importantly, experiments immunoprecipitating PIDD (p53-induced protein with a DD), RAIDD (RIP-associated ICH-1/CED-3-homologous protein with DD) and caspase-2 identify cephalostatin as an experimental drug that induces the formation of the PIDDosome. The bis-steroid cephalostatin proves to be both a helpful tool to investigate apoptotic signaling and a promising chemotherapeutic agent.
\end{abstract}

Cell Death and Differentiation (2008) 15, 1930-1940; doi:10.1038/cdd.2008.125; published online 19 September 2008

We recently characterized cephalostatin 1 , a bis-steroidal marine natural product, to be a promising experimental anticancer agent, as it induces an unusual pathway of apoptosis in leukemia T cells. Briefly, two major pathways leading to apoptosis have been investigated: the one triggered by tumor necrosis factor/CD95 family receptors leading to caspase- 8 activation and the other mediated by mitochondrial release of cytochrome $c$ and other proteins, followed by apoptosome formation and caspase- 9 activation. Cephalostatin 1 causes cell death in a CD95- and caspase-8independent manner. Even more intriguingly, cephalostatin induces apoptosis without triggering cytochrome $c$ release from mitochondria and apoptosome formation. ${ }^{1}$ Apoptosomeindependent cell death induction has been described in the literature before, ${ }^{2,3}$ but it occurred independent of caspase- 9 activation. In contrast, cephalostatin-induced apoptosis is dependent on active caspase- 9 . The activation of caspase- 9 independent of the classical mitochondrial signaling raises the question of the activation pathway of caspase- 9 in cephalostatin-induced apoptosis. Cephalostatin induces a typical endoplasmic reticulum (ER) stress response without the requirement to reroute signaling to the classical mitochondrial pathway and uses caspase-4 to initiate a caspase cascade leading to death. Biochemical and genetic inhibition of caspase-4, however, only partially reduces caspase- 9 activation and the apoptotic efficacy of cephalostatin. ${ }^{4}$ Now in search for further players used by cephalostatin to activate caspase-9 without apoptosome formation, we focused on another unusual feature of cephalostatin signaling, that is, a predominate release of Smac/DIABLO (second mitochondriaderived activator of caspase/direct inhibitor of apoptosisbinding protein with low $\mathrm{pl}$ ) in Jurkat T cells. ${ }^{1}$

$\mathrm{Smac} / \mathrm{DIABLO}$ is a $29 \mathrm{kDa}$ mitochondrial precursor protein, which is proteolytically processed in mitochondria to its $23 \mathrm{kDa}$ mature form. Normally, upon apoptotic stimuli, such as chemotherapeutic drugs, it is released into cytosol together with other mitochondria-located proteins. Smac/DIABLO binds to various inhibitor of apoptosis proteins (IAPs), thus neutralizing their inhibitory effect on caspases. ${ }^{5,6}$ The BIR3 domain of X-linked IAP (XIAP), the most potent member of the IAP family, is recognized by mature Smac/DIABLO. Thus, Smac/DIABLO is able to compete with caspase-9 for binding to the BIR3 domain of IAPs, and thereby favors its activation. Smac/DIABLO also binds to the BIR2 motif of XIAP, thereby counteracting the XIAP-dependent inhibition of caspase-3 and caspase-7. ${ }^{7}$ Besides XIAP, Smac is described to interact with other IAPs, such as IAP-1 and IAP-2, modulating further caspases such as caspase-2. ${ }^{7,8}$ Focusing on the early and strong selective release of Smac upon cephalostatin treatment, we hypothesized that Smac is an important factor in the apoptosome-independent activation of caspase-9. By silencing Smac through siRNA in Jurkat cells, we found indeed a significant impact of this mitochondrial factor on caspase- 9 activation and cell death.

\footnotetext{
${ }^{1}$ Department of Pharmacy, Center for Drug Research, University of Munich, Munich, Germany; ${ }^{2}$ Chemistry Department, Arizona State University, Tempe, AZ, USA; ${ }^{3}$ Department of Pharmacognosy, University of Vienna, Vienna, Austria; ${ }^{4}$ Interfaculty Institute for Biochemistry, University of Tübingen, Tübingen, Germany; ${ }^{5}$ Department of Physiology and Medical Physics, RCSI Research Institute, Dublin, Ireland and ${ }^{6}$ University Children's Hospital, Ulm, Germany

*Corresponding author: AM Vollmar, Department of Pharmacy, Center for Drug Research, University of Munich, Butenandtstr. 5-13, D-81377 Munich, Germany. Tel: + 49892180771 72; Fax: + 49892180771 73; E-mail: Angelika.Vollmar@cup.uni-muenchen.de Keywords: apoptosis; PIDDosome; caspase-2; caspase-9; calcium; Jurkat

Abbreviations: PIDD, p53-induced protein with a DD; RAIDD, RIP-associated ICH-1/CED-3-homologous protein with DD; Smac/DIABLO, second mitochondriaderived activator of caspase/direct inhibitor of apoptosis-binding protein with low pl; BIR, baculovirus IAP repeat; IAP, inhibitor of apoptosis; YFP, yellow fluorescent protein; GFP, green fluorescent protein; PARP, poly-ADP-ribose-polymerase

Received 10.9.07; revised 23.7.08; accepted 30.7.08; Edited by W El-Deiry; published online 19.9.08
} 
Most interestingly, activation of caspase- 2 by cephalostatin was markedly reduced in Jurkat $T$ cells lacking Smac. We show that caspase-2 acts as initiator caspase in the signaling orchestra leading to cephalostatin-induced cell death and that it is recruited to the recently described PIDDosome complex.

\section{Results}

Smac but not cytochrome $c$ is predominately released in various tumor cells upon cephalostatin treatment. We have previously shown that cephalostatin induces the selective mitochondrial release of Smac but not cytochrome $c$ in Jurkat leukemia $T$ cells. ${ }^{1}$ To further confirm that this unusual finding is not a cell type-specific phenomenon, but a characteristic event for cephalostatininduced apoptosis, we investigated the release of Smac and cytochrome $c$ in two further cell lines, SK-Mel-5 and MCF-7 cells. As seen in Figure 1a, Smac - in contrast to cytochrome $c-$ is rapidly and markedly released from mitochondria upon cephalostatin treatment, whereas staurosporine and etoposide induce the translocation of both proteins into cytosol. These results were further supported by confocal microscopy studies using MCF-7 cells expressing either cytochrome $c$-green fluorescent protein (GFP) or Smacyellow fluorescent protein (YFP) (Figure 1b). Untreated control cells show the colocalization of cytochrome $c$-GFP and Smac-YFP with a mitochondrial dye, proofing the mitochondrial localization of the fusion proteins. After stimulation with cephalostatin, Smac-YFP is found in the cytosol, whereas cytochrome $c$-GFP is still mitochondrialocalized. In contrast, staurosporine induces the release of both proteins.

Cephalostatin-induced Smac release involves $\mathrm{Bcl}-2$ family proteins. Smac can be released from mitochondria in several ways. A few reports ${ }^{9,10}$ show that Jun $\mathrm{N}$-terminal kinase (JNK) is involved in the release of Smac from mitochondria. As cephalostatin activates $\mathrm{JNK}^{11}$ we investigated the impact of JNK and its upstream regulatory kinase ASK1 on cephalostatin-induced Smac release. As shown in Figure $2 a$, neither the inhibition of JNK by the inhibitor SP600125 nor the use of Jurkat cells that express an inactive form of ASK1 could prevent cephalostatin-induced Smac release.

In search for factors responsible for Smac release, we investigated the impact of $\mathrm{Bcl}-2$ proteins. Interestingly, as shown in Figure 2b, Bak deficiency does not delay Smac release in cephalostatin-treated Jurkat cells and does not affect apoptotic activity of cephalostatin as shown before. ${ }^{6}$ In contrast, overexpression of $\mathrm{Bcl}-2$ and downregulation of Bim by siRNA are able to reduce Smac translocation to cytosol (Figure 2c) at $4 \mathrm{~h}$, pointing to an initial role of those two proteins in the mechanism of Smac release. The $\mathrm{Ca}^{2+}$. dependent calpain family of cysteine proteases is known to mediate apoptosis upon several conditions, among others, by cleaving Bcl-2 family proteins and inducing the release of mitochondrial factors. Calpain is activated upon $\mathrm{Ca}^{2+}$ binding and further autolytic processing to its $76 \mathrm{kDa}$ subunit. ${ }^{12}$ In fact, cephalostatin leads to a rapid calcium release and calpain activation already after $1 \mathrm{~h}$ of treatment (Figure 2d). Owing to this fast activation, we investigated a possible influence of calpain on the selective Smac release by using the inhibitor calpastatin. Interestingly, cephalostatin-induced Smac release into the cytosol was slightly diminished by calpain inhibition (Figure 2d). Densitometric analysis added up to approximately $20 \%$ inhibition of Smac release. However, calpain inhibition did not reveal a significant effect on apoptotic activity of cephalostatin (data not shown).

\section{Smac enhances the apoptotic signaling cascade} induced by cephalostatin. Owing to the unique characteristic of cephalostatin to induce a selective Smac release, we investigated the role of Smac in cephalostatininduced cell death by silencing the Smac gene by siRNA. As shown in Figure 3, silencing of Smac significantly inhibited cephalostatin-induced apoptosis. As Smac is known to abolish the inhibitory effect of XIAP on caspase-9 and caspase-3, we investigated the effect of Smac downregulation on cephalostatin-mediated caspase activation. Silencing of Smac clearly suppressed the appearance of caspase- 9 cleavage products, indicating a reduced activation of the initiator caspase- 9 in Smacdepleted cells. In contrast, activation of the initiator caspase-4 was only slightly affected by the absence of Smac, and might be delayed (Figure 4a). Smac siRNA had also influence on caspase-3 activation and consequently PARP (poly-ADP-ribose-polymerase) cleavage as shown in Figure $4 \mathrm{~b}$ by reduced caspase- 3 cleavage products and strongly diminished appearance of the $85 \mathrm{kDa}$ PARP fragment. Caspase-2 has characteristics of an initiator caspase owing to its long CARD-containing prodomain. The prodomain and the linker region between the large and the small subunit are removed during generation of the active enzyme, resulting in different cleavage products. ${ }^{13}$ Interestingly, cephalostatin-induced processing of caspase2 to its $18 \mathrm{kDa}$ fragment was prevented upon Smac silencing (Figure 4a), pointing to a participation of caspase-2 in cephalostatin-induced cell death.

Cephalostatin-induced activation of caspase-2 is involved in apoptosis. In fact, treatment of cells with cephalostatin leads to an early activation of caspase-2, as demonstrated in Figure $5 \mathrm{a}$, by the appearance of the caspase-2 cleavage product p31 already after $4 \mathrm{~h}$ of incubation. Thapsigargin was used as positive control. The caspase-2 inhibitor zVDVAD-fmk reduced DNA fragmentation induced by cephalostatin and thapsigargin (Figure 5b), indicating that caspase-2 contributes to cephalostatin-mediated apoptosis. This result was further supported by siRNA experiments. Cells transiently transfected with a siRNA targeting caspase-2 showed a significantly reduced amount of annexin $\mathrm{V}$-positive cells as compared with cells transfected with a scrambled siRNA sequence (Figure 5b). Although these results confirm a contribution of caspase-2 in cephalostatin-induced apoptosis, the impact might be of minor importance and draws attention to another proapoptotic factor, namely caspase-4. In addition to caspase-2, caspase-4 is involved 
in the early steps of cephalostatin-induced cell death. ${ }^{4}$ Thus, we examined the impact of the concomitant inhibition of caspase-4 and caspase-2 on cephalostatin-induced apoptosis by employing the selective inhibitors zLEVD-fmk and zVDVAD-fmk. Figure $5 c$ shows an almost complete inhibition of cephalostatin-induced DNA fragmentation upon pre-incubation with both inhibitors together, demonstrating the essential role of caspase- 4 and caspase- 2 . a SK-Mel-5
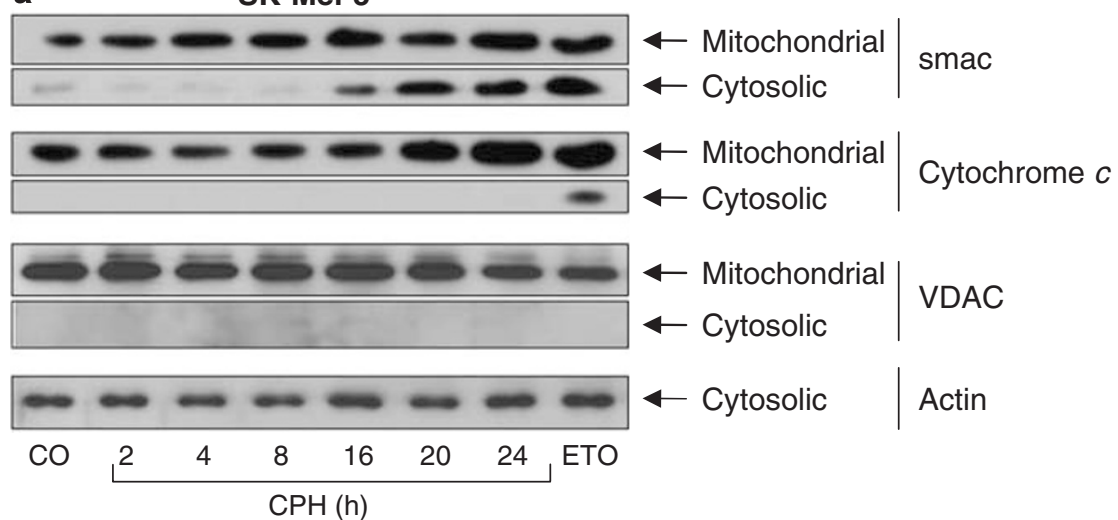

MCF-7

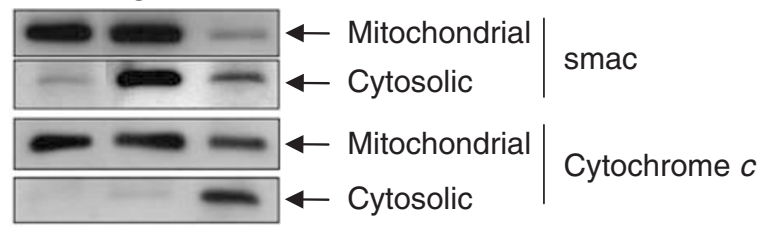

\begin{tabular}{|l|l|l|l}
\hline$\longleftarrow \infty$ & $\leftarrow$ Mitochondrial & VDAC \\
\hline \hline$\cdots$ & $\leftarrow$ Cytosolic &
\end{tabular}

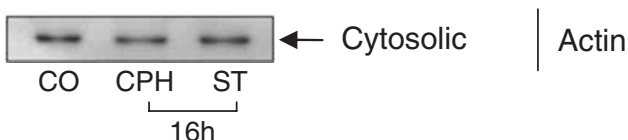

b

MCF-7 smac-YFP

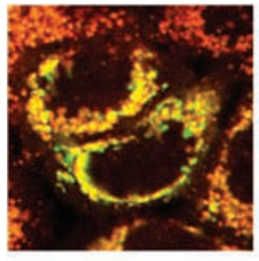

$\mathrm{CO}$

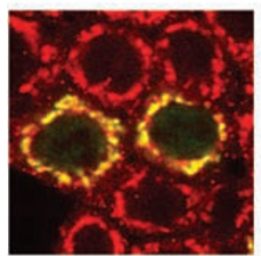

$\mathrm{CO}$

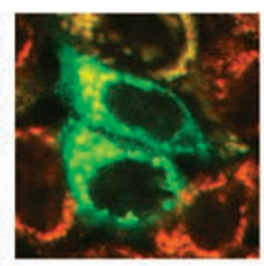

8h $\mathrm{CPH}$

MCF-7 cyt c-GFP

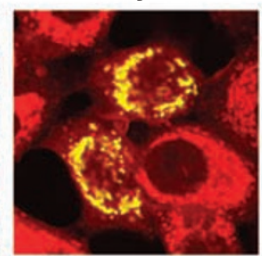

8h $\mathrm{CPH}$

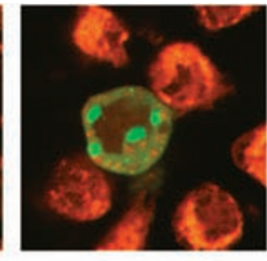

8h ST

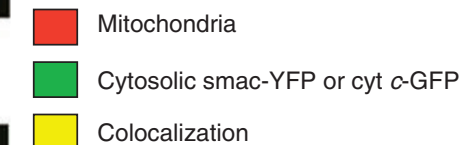

Colocalization

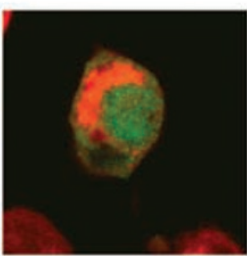

8h ST

Figure 1 Smac is selectively released upon cephalostatin treatment regardless of cell type. (a) SK-Mel-5 and MCF-7 cells were either left untreated (CO) or treated with cephalostatin $2(\mathrm{CPH} ; 50 \mathrm{nM})$, staurosporine $(\mathrm{ST} ; 1 \mu \mathrm{M})$ or etoposide (ETO; $10 \mu \mathrm{M})$ for the indicated times. Smac and cytochrome $c$ release were analyzed by Western blot. VDAC served as control for the purity of the cytosolic fractions and actin was used as loading control. Experiments were carried out three times. (b) MCF-7 cells stably expressing either cytochrome $c$-GFP or smac-YFP were left untreated (CO) or treated with cephalostatin $2(\mathrm{CPH} ; 50 \mathrm{nM})$ or staurosporine (ST; $1 \mu \mathrm{M})$ for $8 \mathrm{~h}$. Smac and cytochrome $c$ release were analyzed by confocal microscopy. Mitochondria are shown in red; merge of mitochondria with cytochrome $c$-GFP or Smac-YFP is shown yellow. Smac and cytochrome $c$ released into cytosol is displayed green. Experiments were carried out three times 
Caspase-2 is activated independent of caspase-9 upon cephalostatin treatment. Caspase-2 can be activated upstream ${ }^{14,15}$ or downstream ${ }^{16}$ of caspase-9. We hypothesized that, in addition to caspase-4, caspase- 2 could act as an apical caspase in cephalostatin-induced apoptosis. To this end, activation of caspase-2 was examined in caspase-9deficient and caspase-9-reconstituted cells, and activation of caspase-9 was investigated in caspase-2-silenced cells. Caspase-2 activation upon cephalostatin is independent of caspase-9, as shown in caspase-9-deficient (Caspase 9-/-) and caspase-9-reconstituted (Caspase $9+/+$ ) Jurkat cells (Figure 6a, upper panel). On the other hand, caspase-9 is activated to the same extent in caspase-2-silenced and -scrambled siRNA-transfected cells (Figure 6a lower panel). Thus, cephalostatin-induced caspase-2 does not affect caspase-9 activation, which differs from the role of cephalostatin-induced caspase-4. Caspase-2 appears to act as initiator caspase and independent of caspase-9. In a next step, we were interested in the mechanism of this initial caspase-2 activation induced by cephalostatin.

Cephalostatin induces recruitment of Caspase-2 to the PIDDosome complex. Although processing of caspase-2 to its active fragments was observed after $4 \mathrm{~h}$ of treatment with cephalostatin, similar to caspase-9, recruitment to a large protein complex (independent of the Apaf-1 apoptosome) is sufficient to mediate its activation. ${ }^{17}$ Later, appearance of cleavage fragments is mediated by self-processing and further enhances its catalytic activity. ${ }^{13}$ This newly identified caspase-2-activating protein complex is referred to as the PIDDosome,$^{18}$ composed of the proteins PIDD (p53-induced protein with a DD), RAIDD (RIP-associated $\mathrm{ICH}-1 / \mathrm{CED}-3$-homologous protein with $\mathrm{DD}$ ) and procaspase-2. To investigate the participation of the PIDDosome in our system, we studied the protein interaction by immunoprecipitation of caspase-2, RAIDD and PIDD. Western blot analysis of the precipitation complex of each antibody reveals the basal interaction of RAIDD and PIDD in untreated cells (Figure 6b). Importantly, upon $1 \mathrm{~h}$ of incubation with cephalostatin, procaspase-2 is recruited to the PIDD and RAIDD complex (Figure 6b), suggesting the assembly of the PIDDosome as the possible mechanism of caspase-2 activation. As Smac is necessary for caspase-2 activation in cephalostatin-treated cells, we further investigated the impact of Smac on PIDDosome formation by silencing Smac by siRNA experiments. Here we observed almost no reduction in PIDD recruitment to caspase-2 in the absence of Smac (Figure 6c).

\section{Discussion}

Our presented work reports an unusual apoptotic signaling pathway induced by the experimental chemotherapeutic drug cephalostatin and communicates two new major findings. First, selectively released Smac was demonstrated to increase caspase activity, and therefore cell death upon cephalostatin treatment. Interestingly, apart from caspase-9 and caspase-3, mainly caspase-2 activity was affected by Smac. Second, caspase-2 acted as an initiator caspase and contributed independent of caspase-9 to cephalostatininduced cell death. Cephalostatin has been reported earlier to activate caspase-9 apoptosome-independent and partially through ER stress. ${ }^{4}$ Here, we show that cephalostatin is able to induce formation of the PIDDosome.

The release of mitochondrial intermembrane space proteins to the cytosol is a key event during apoptosis. For instance, cytochrome $c$ is required for the initiation of the apoptosome and activation of caspases, whereas Smac/DIABLO is believed to enhance caspase activation through the neutralization of the IAPs. ${ }^{19}$ Upon apoptotic stimuli, these mitochondrial factors are usually released together in a manner that is coordinately initiated. ${ }^{20}$ Thus, the fact that cephalostatin leads to a marked and early Smac release without detectable amounts of cytochrome $c$ deserves attention and asks for the mechanism of release as well as for the impact of Smac in cephalostatininduced cell death.

Similar to our data, the group of Anderson ${ }^{10,21}$ reported about an Apaf-1/cytochrome $c$-independent and Smacdependent induction of apoptosis in multiple myeloma cells by dexamethasone. The authors identified activated JNK to be responsible for Smac release using the JNK inhibitor SP600125. Cephalostatin is also able to rapidly induce JNK activation. ${ }^{11}$ However, blocking JNK activity through SP600125 or overexpression of a dominant-negative form of its upstream kinase ASK1 in our hands did not affect Smac release (Figure 2a). First experiments show that the absence of the proapoptotic Bcl-2 protein Bak has no influence on Smac release (Figure 2c), suggesting that cephalostatin may trigger another signal directly influencing the mitochondrial pore formation. Another $\mathrm{Bcl}-2$ protein, Bim (Bcl-2 interacting mediator of cell death), antagonizes pro-survival Bcl-2 family members. ${ }^{22}$ Upon apoptotic stimuli, Bim is reported to translocate to mitochondria, directly interacting with $\mathrm{Bcl}-2$, and thereby releasing proapoptotic factors from the intermembrane space of the mitochondria to the cytosol. ${ }^{23}$ Indeed, we found that overexpression of the anti-apoptotic protein $\mathrm{Bcl}-2$ as well as downregulation of the proapoptotic factor Bim reduces cytosolic Smac. This is also in line with our previous findings that overexpression of the anti-apoptotic $\mathrm{Bcl}-2$ family member Bcl- ${ }_{x \mathrm{~L}}$ delays cephalostatin-induced Smac translocation into the cytosol. ${ }^{1}$ The calpain family of proteases appears to be an important factor in the induction of apoptosis through the mitochondria, as Bax has been identified as a target of calpain ${ }^{24}$ and calpain inhibition has been shown to inhibit the release of Smac and cytochrome $c$ from the mitochondria. ${ }^{12}$ Calpain is rapidly activated upon cephalostatin treatment and is partially involved in the selective Smac release (Figure 2d), further supporting the crosstalk between calpain and mitochondria.

Smac has been discovered in the search for proteins that are able to interact with mammalian and baculoviral IAPs. ${ }^{5}$ IAPs, which are characterized by one or more baculovirus IAP repeat (BIR), antagonize caspases by binding to and inhibiting mainly caspase- $-9,-3$ and $-7 .{ }^{25}$ Smac has been reported to promote apoptosis in response to various apoptosis inducers by antagonizing IAP-mediated inhibition of caspases. ${ }^{26}$ To this end, Smac agonists sensitized various tumor cells for cell death. ${ }^{27,28}$ We used siRNA technique to silence the Smac gene and subsequently examined the impact of endogenous Smac released upon cephalostatin treatment. As expected, we observed a strong reduction in caspase- 9 as well as caspase-3 activation. A moderate effect of caspase-4 activa- 
tion in Smac-depleted cells was seen. Taken together, our results demonstrate an essential role of Smac in cephalostatin-induced caspase cascade most likely by promoting caspase activity. In this respect, the fact that caspase-2 activity triggered by cephalostatin is markedly reduced in cells depleted by Smac draws attention to caspase-2 as a further caspase involved in the apoptosome-independent cell death induced by cephalostatin.

Even though caspase-2 was the second mammalian caspase identified, its exact role in the regulation of cell death is controversial and relatively unknown, in part, due to its different function dependent on cell type and stimulus. Caspase-2 contains a CARD domain and can act as initiator caspase ${ }^{14,15,29}$ but has characteristics of effector caspases $^{30,31}$ too. It is localized not only predominantly in the Golgi complex and the nucleus, but also in the mitochondria and cytosol. ${ }^{32}$ Many reports exclude an essential role of caspase-2 in apoptosis presumably due to the compensation by other caspases. ${ }^{16,33}$ However, caspase-2 is activated in response to DNA damage, where it acts as the only initiator caspase, ${ }^{32}$ and appears necessary for apoptosis triggered by ultraviolet irradiation, ${ }^{29}$ trophic factor with-

a

ASK-DN

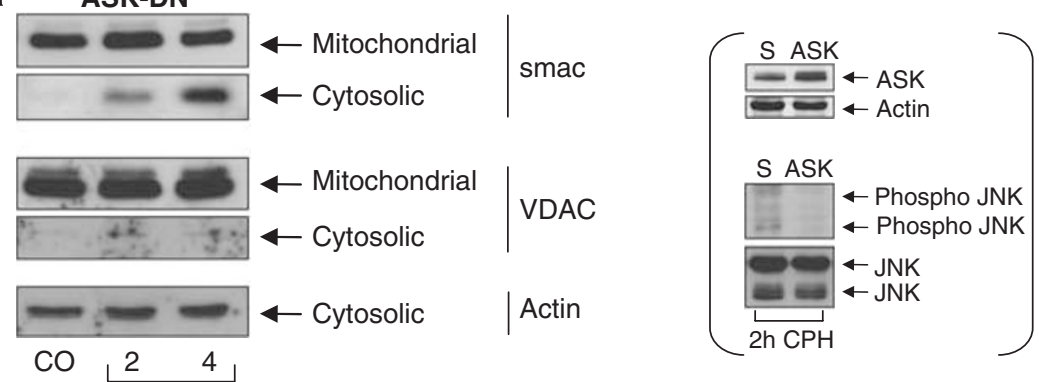

$\mathrm{CPH}(\mathrm{h})$
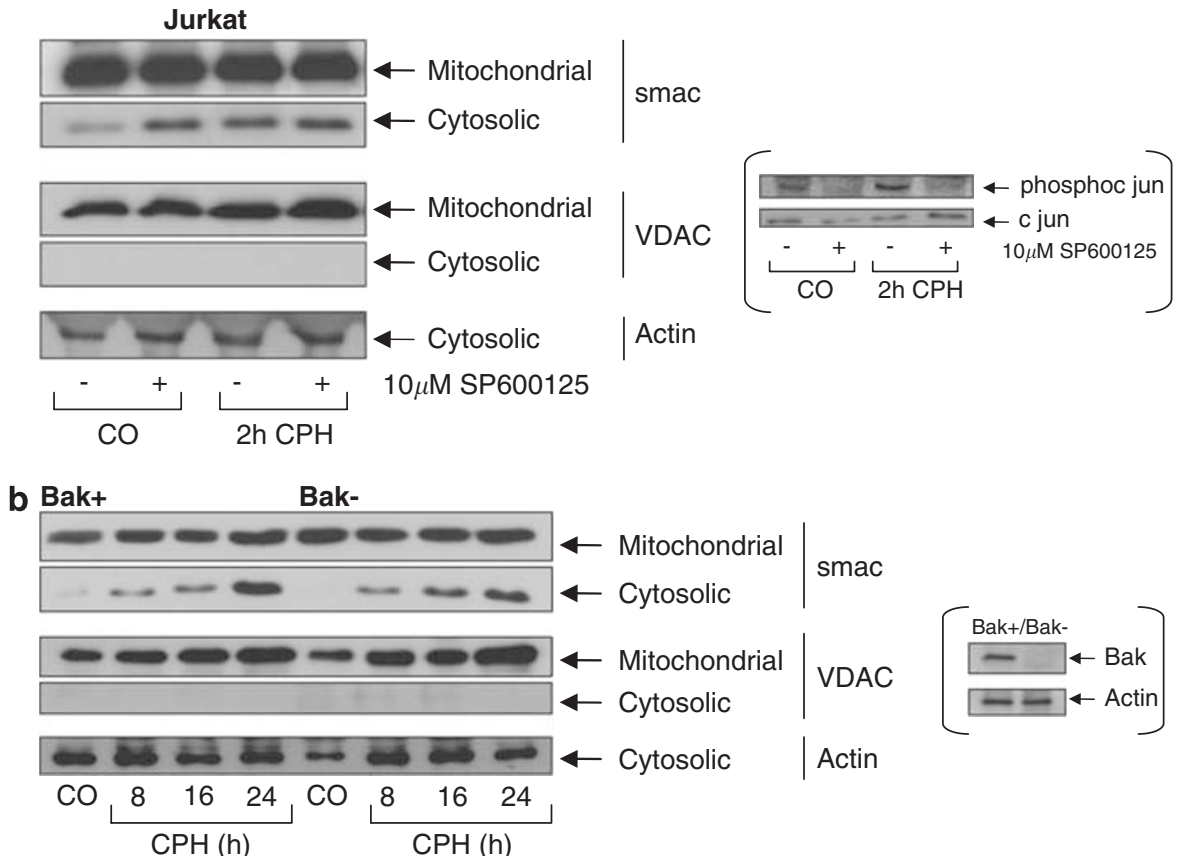

Figure 2 Cephalostatin-induced Smac release is not dependent on JNK, but is partially dependent on Bcl-2, Bim and calpain. (a) ASK1-DN (ASK-DN) and Jurkat cells were left untreated $(\mathrm{CO})$ or treated with cephalostatin $2(\mathrm{CPH} ; 50 \mathrm{nM})$ for the indicated times, and Jurkat cells were pretreated for 30 min with $10 \mu \mathrm{M}$ SP600125. Smac release was analyzed by Western blot. VDAC served as control for the purity of the cytosolic fractions and actin was used as loading control. Experiments were carried out three times. Insets (on the right) show the functionality of both the ASK1-DN construct and the JNK inhibitor SP600125. (b) Bak reconstituted (Bak + ) and Bak deficient (Bak-) Jurkat cells were left untreated $(\mathrm{CO})$ or treated with cephalostatin $2(\mathrm{CPH} ; 50 \mathrm{nM})$ for the indicated times. Smac release was analyzed by Western blot. VDAC served as control for the purity of the cytosolic fractions and actin was used as loading control. Experiment was carried out three times. Inset shows Bak levels. (c) Bcl-2 overexpressing (Bcl-2) and vector control (Neo) Jurkat cells, as well as Jurkat cells transfected with Bim (Bim siRNA) or scrambled (scr) siRNA were left untreated (CO) or treated with cephalostatin 2 $(\mathrm{CPH} ; 50 \mathrm{nM})$ for the indicated times. Smac release was analyzed by Western blot. VDAC served as control for the purity of the cytosolic fractions and actin was used as loading control. Experiments were carried out two times. Insets show Bcl-2 level in Bcl-2 and Neo cells, and downregulation of Bim in Bim siRNA-transfected cells. (d) Upper panel: Jurkat cells were incubated with Fura-2-AM and treated with cephalostatin and thapsigargin. Calcium release was measured by increase in the ratio of the $340 \mathrm{~nm} /$ $380 \mathrm{nM}$ fluorescence. A representative experiment out of three is shown. Middle panel: Jurkat cells were left untreated (CO) or treated with cephalostatin for the indicated times. The calcium ionophore A23187 (A; $1 \mu \mathrm{M} 16 \mathrm{~h}$ ) was used as positive control. Calpain activation was analyzed by Western blot. Lower panel: Jurkat cells were left untreated $(\mathrm{CO})$ or treated with cephalostatin $(\mathrm{CPH}, 50 \mathrm{nM})$ for $2 \mathrm{~h}$. Before $1 \mathrm{~h}$ stimulation, cells were incubated with $500 \mathrm{nM}$ calpastatin-penetratin (inset shows its functionality). Experiments were carried out three times. Smac release was analyzed by Western blot. VDAC served as control for the purity of the cytosolic fractions and actin was used as loading control 
C

$\mathrm{NeO}-\mathrm{Bcl}$

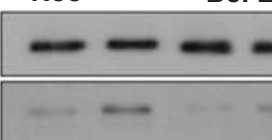

$$
\leftarrow \text { Mitochondrial }
$$

$\longleftarrow$ Cytosolic

smac
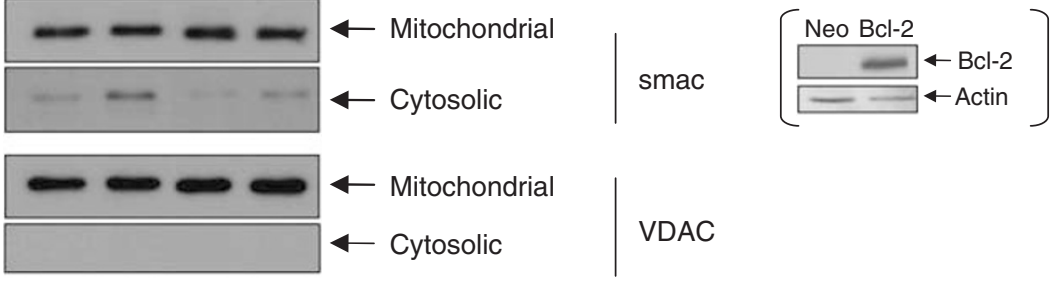

$\longleftarrow$ Mitochondrial

$\leftarrow$ Cytosolic

VDAC

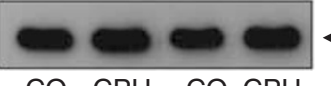

$\longleftarrow$ Cytosolic

Actin

$\mathrm{CO} \mathrm{CPH} \quad \mathrm{CO} \mathrm{CPH}$

scr BIM SIRNA
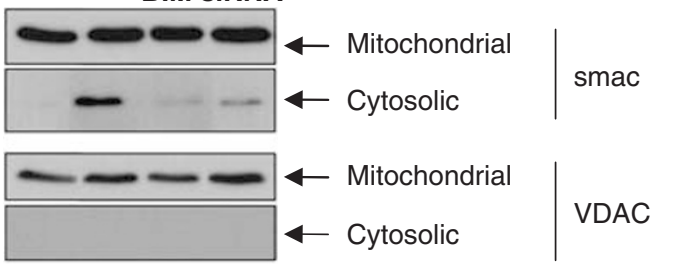

VDAC

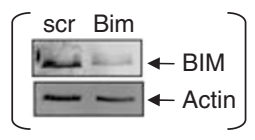

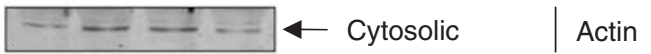

$\mathrm{CO} \mathrm{CPH} \mathrm{CO} \mathrm{CPH}$
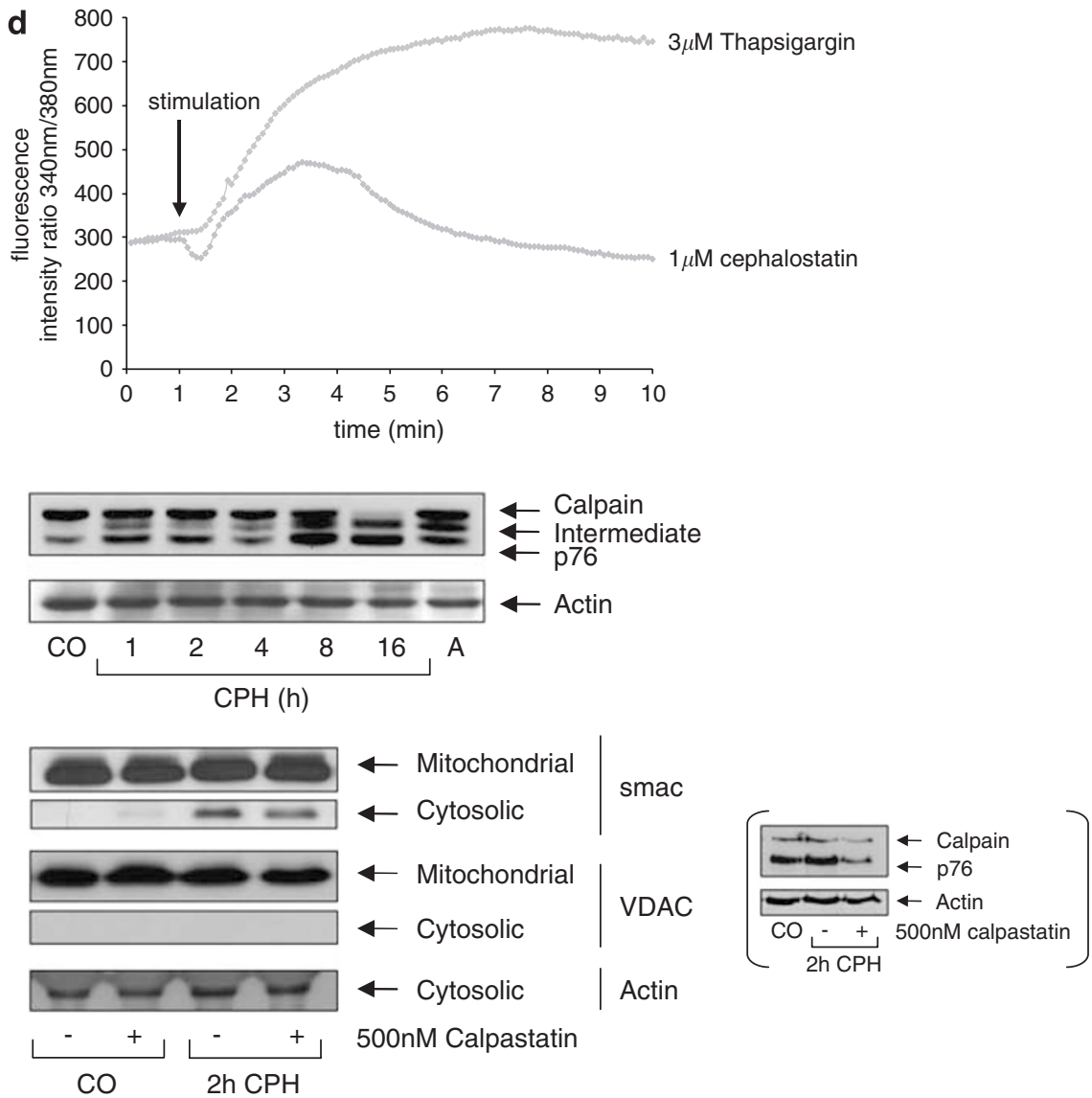

Figure 2 (Continued)

drawal $^{34}$ or administration of TRAIL. ${ }^{35}$ Caspase-2 has also been implicated in neuronal death induced by $\beta$-amyloid ${ }^{36}$ and recently in ER stress. ${ }^{8}$ We depleted caspase-2 through siRNA transfection and observed a minor but significant effect on the extent of apoptotic cell death induced by cephalostatin. Use of the caspase-2 inhibitor zVDVAD-fmk results in a similar reduction of cell death, indicating that caspase- 2 is involved in the unusual apoptotic pathway induced by cephalostatin. The 


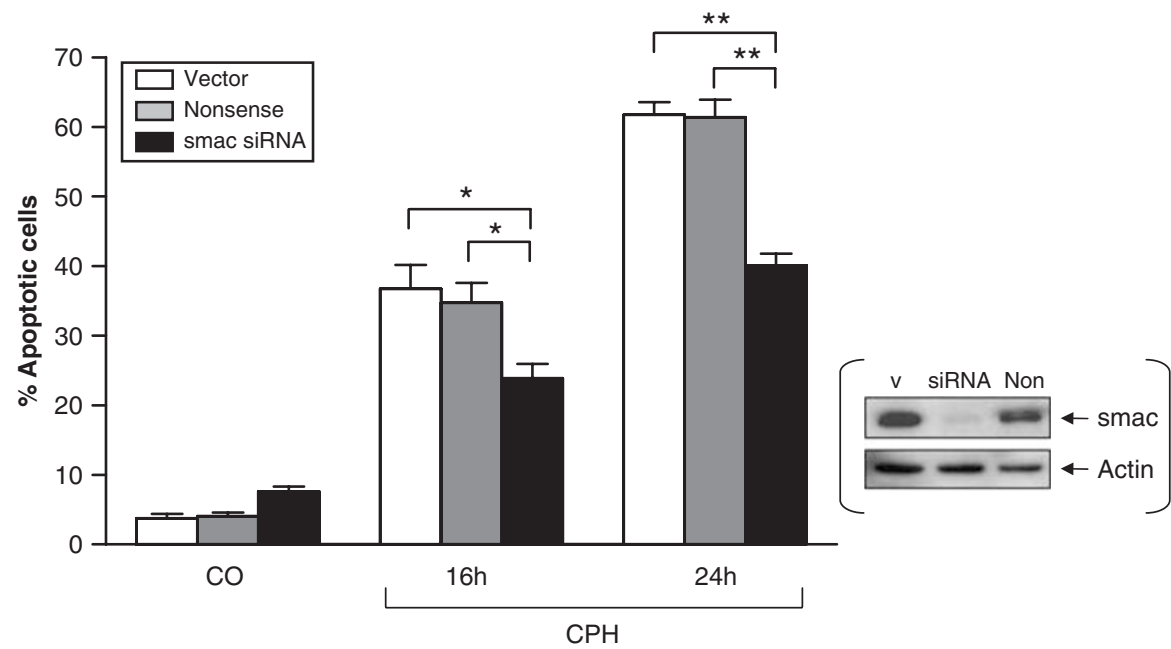

Figure 3 Smac siRNA inhibits cephalostatin 2-induced cell death. Jurkat cells were transfected with plasmids encoding for either Smac siRNA or nonsense sequence or vector without inset. Cells were left untreated $(\mathrm{CO})$ or treated with cephalostatin $2(\mathrm{CPH} ; 50 \mathrm{nM})$ for the indicated times. Apoptotic cells were quantified by flow cytometry as described in 'Materials and Methods.' Downregulation was verified by Western Blot (see inset). Equal protein loading was controlled by actin. All experiments were carried out three times. Bars, the mean \pm S.E.M. of three independent experiments. ${ }^{*} P<0.05 ;{ }^{* *} P<0.01$ (unpaired two-tailed $t$-test)

question arises as to whether caspase- 2 is functioning as an initiator or as an effector caspase. Both roles have been described earlier. ${ }^{15,16,29}$ The fact that caspase-2 is activated in caspase-9-deficient cells similar to caspase-9-reconstituted Jurkat cells clearly votes for caspase-2 activation to be an upstream event. Importantly, caspase-2 activation is not involved in apoptosome-independent activation of caspase- 9 as reported earlier for cephalostatin-induced caspase- 4.4

Our next step was to understand how caspase-2 is activated upon cephalostatin treatment. In this respect, most interestingly caspase- 2 was reported to be activated by recruitment into a large multiprotein complex independent of Apaf- 1 and cytochrome $c .^{17}$ This putative complex has been proposed to be the PIDDosome ${ }^{18}$ formed by the association of the protein PIDD (p53-induced protein with a DD), RAIDD (RIP associated ICH-1/CED-3-homologous protein with DD) and procaspase-2. The PIDDosome was proposed to regulate caspase-2 activation and apoptosis induced by genotoxic agents. Upon recruitment to the complex, caspase-2 was activated and autoprocessed, but it was not clear whether activated caspase-2 was involved in cell death. ${ }^{18}$ RAIDD together with caspase- 2 has been recently demonstrated to participate in the induction of apoptosis under conditions of trophic factor withdrawal but not DNA damage, ${ }^{34}$ arguing against the exclusive formation of the caspase-2 activation complexes by genotoxic stress. ${ }^{18}$ Along this line, cephalostatin does not induce DNA damage ${ }^{11}$ and is, to our best knowledge, one of the few drugs ${ }^{37,38}$ that have clearly shown to induce the recruitment of caspase-2 to PIDD and RAIDD, leading to the formation of the PIDDosome. As cephalostatininduced caspase-2 activation was prevented in Smacdepleted cells, we were interested whether Smac is involved in the recruitment of caspase-2 into the PIDDosome. PIDD binding to caspase-2 still occurs in the absence of Smac. Thus, the formation of the PIDDosome appears to be independent on Smac. We therefore hypothesize that Smac and not PIDDosome formation itself is most likely to be the crucial and final step in caspase- 2 activation by cephalostatin.

In summary, the experimental drug cephalostatin, which was isolated from a marine organism, proved to be both a very valuable tool to discover novel aspects in apoptotic signaling and to be a promising therapeutic agent promoting apoptosis.

\section{Materials and Methods}

Compounds. Cephalostatins (CPH) 1 and 2 were kindly provided by Dr. GR Pettit and were isolated from the marine worm Cephalodiscus gilchristi. Cephalostatins 1 and 2 share the same apoptotic profile as examined in pilot experiments (data not shown). Thus, experiments were performed either with cephalostatin 1 or cephalostatin 2 without distinction. Purity of the compound was $98 \%$ as judged by high-performance liquid chromatography analysis. Before application, cephalostatins 1 and 2 were dissolved in DMSO. Final DMSO concentration did not exceed 1\%, a concentration verified not to interfere with the experiments performed. Etoposide (ETO) and the JNK inhibitor SP600125 were purchased from Calbiochem (Bad Soden, Germany). Staurosporine (ST) was from Biozol (Eching, Germany). Propidium iodide (PI) and thapsigargin (TG) were from Sigma (Deisenhofen, Germany). The caspase-2 inhibitor zVDVAD-fmk was obtained from MBL (Woburn, Massachusetts, USA). Calpastatin exon 1B-derived peptide was synthesized by Gene Center (Munich, Germany), and the activated cell-permeable peptide penetratin 1 was purchased from Qbiogene (Morgan Irvine, CA, USA). The activated penetratin was coupled onto the calpastatin exon 1B-derived peptide by incubating both peptides at an equimolar ratio for $2 \mathrm{~h}$ at room temperature. The conjugated peptide functioned as calpain inhibitor. ${ }^{39}$ Fura-2-AM (Fura-2 acetoxymethyl ester), used for calcium measurement, was purchased from Biotrend (Cologne, Germany).

Cell culture. Human leukemia Jurkat T cells (J16), Bak-deficient Jurkat cells (Bak-, JCaM1.6), deficient cells reconstituted with Bak (Bak+), Bcl-2 overexpressing and vector control (neo) cells, a Jurkat cell line expressing an inactive form of ASK1 (ASK1-DN, clone A2-3) and Jurkat T cells lacking caspase-9 (Casp 9-/-) or reconstituted with caspase-9 (Casp $9+/+$ ) were cultured $\left(37^{\circ} \mathrm{C}\right.$ and $5 \% \mathrm{CO}_{2}$ ) in RPMl 1640 containing $2 \mathrm{mM} \mathrm{L-glutamine} \mathrm{(PAN} \mathrm{Biotech,} \mathrm{Aidenbach,}$ Germany) supplemented with 10\% FCS (PAA Laboratories, Cölbe, Germany) and $1 \%$ pyruvate (Merck Biosciences, Darmstadt, Germany). MCF-7, MCF-7 cytochrome c-GFP and MCF-7 Smac-YFP cells were cultured in RPMI 1640 containing $2 \mathrm{mM}$ L-glutamine supplemented with $10 \%$ heat-inactivated FCS and $1 \%$ pyruvate. The melanoma cell line SK-Mel-5 (ATCC) was cultured in DMEM supplemented with $2 \mathrm{mM} \mathrm{L-glutamine,} 10 \% \mathrm{FCS}$ and $1 \%$ pyruvate. 


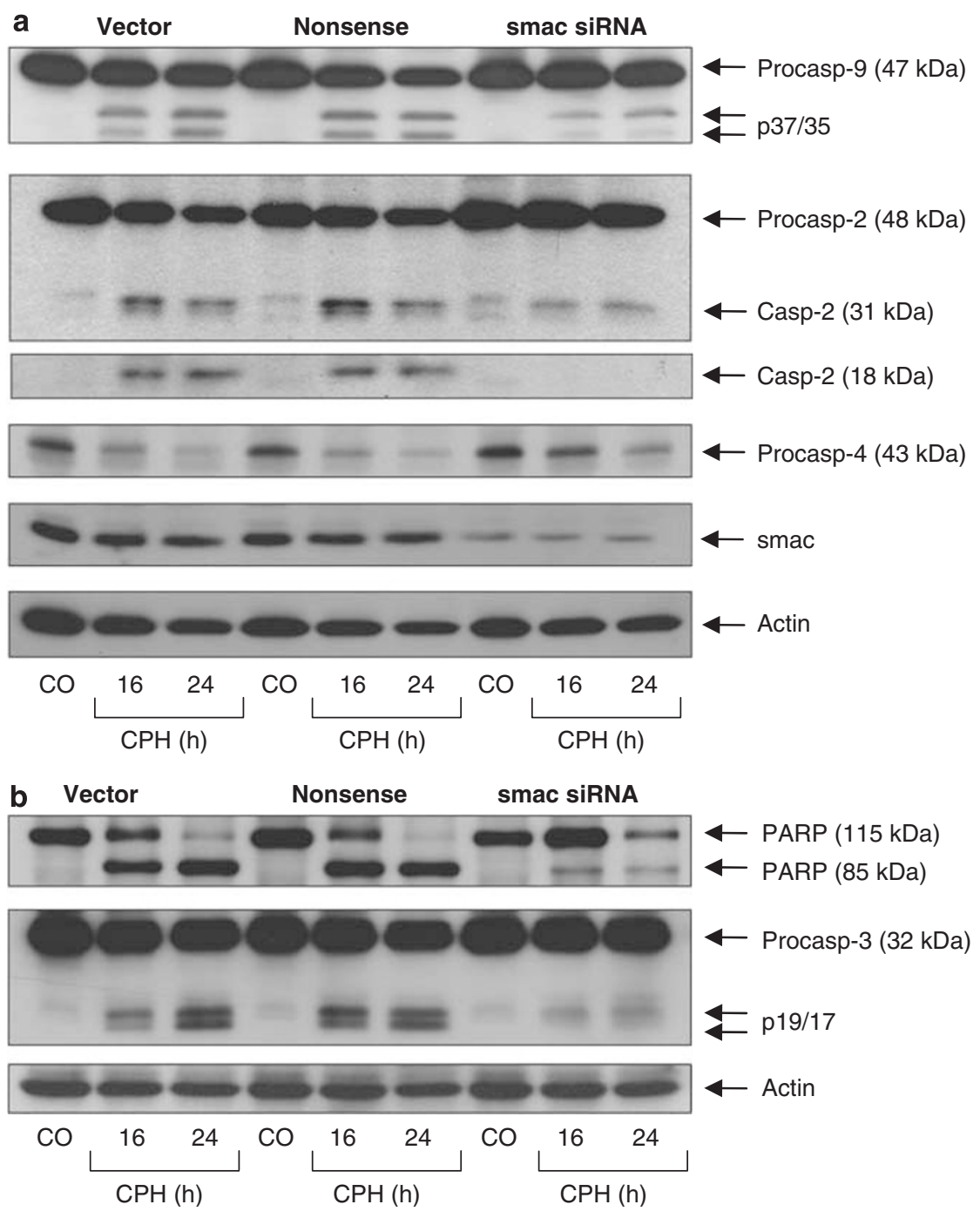

Figure 4 Smac silencing reduces the activation of caspase-9, caspase-3 and caspase-2. Jurkat cells were transfected with plasmids encoding for either Smac siRNA or nonsense sequence or with vector alone as described in 'Material and Methods.' Cells were left untreated (CO) or treated with cephalostatin 2 (CPH; $50 \mathrm{nM}$ ) for the indicated times. Activation of caspase-9, caspase-2, caspase-3 and caspase-4, as well as PARP cleavage was examined by Western blot. Experiments were carried out three times. Transfection efficacy was analyzed by Western blot for Smac. Equal protein loading was controlled by actin

\section{Quantification of apoptosis}

Propidium iodide staining. Quantification of apoptosis was performed as described earlier. ${ }^{4}$ Briefly, cells were incubated in a buffer containing $0.1 \%$ sodium citrate, $0.1 \%$ Triton X-100 and $50 \mu \mathrm{g} / \mathrm{ml} \mathrm{PI}$ overnight at $4{ }^{\circ} \mathrm{C}$ and analyzed by flow cytometry on a FACSCalibur (Becton Dickinson, Heidelberg, Germany). Nuclei to the left of the $G_{1}$-peak were considered apoptotic.

Analysis of phosphatidylserine exposure. Phosphatidylserine translocation to the outer leaflet of the plasma membrane was analyzed by the Annexin V-FITC Detection Kit (Bender MedSystems, Vienna, Austria) according to the manufacturer's instructions. Cells were analyzed by flow cytometry on a FACSCalibur. Only annexin V-positive and PI-negative cells were considered apoptotic.

Western blot analysis. Cells were collected by centrifugation, washed with ice-cold PBS and lysed in 1\% Triton X-100, $150 \mathrm{mM} \mathrm{NaCl}, 2 \mathrm{mM}$ EDTA and $30 \mathrm{mM}$ Tris- $\mathrm{HCl}$ pH 7.5 with the protease inhibitor Complete ${ }^{\mathrm{TM}}$ (Roche, Mannheim, Germany) for $30 \mathrm{~min}$. Lysates were homogenized with an ultrasonic device and centrifuged at $10000 \times g$ for $10 \mathrm{~min}$ at $4^{\circ} \mathrm{C}$.
Analysis of cytochrome $c$ and Smac release. Release of cytochrome $c$ and Smac from mitochondria was analyzed as described earlier. ${ }^{1}$ Briefly, cell pellets were resuspended in permeabilization buffer $(210 \mathrm{mM}$ D-mannitol, $70 \mathrm{mM}$ sucrose, $10 \mathrm{mM}$ HEPES, $5 \mathrm{mM}$ succinate, $0.2 \mathrm{mM}$ EGTA, $0.15 \%$ bovine serum albumin, $60 \mu \mathrm{g} / \mathrm{ml}$ digitonin, $\mathrm{pH}$ 7.2) and incubated for $20 \mathrm{~min}$ at $4{ }^{\circ} \mathrm{C}$. Permeabilized cells were centrifuged (1500 r.p.m.), the supernatant was removed and centrifuged again (10 min, $14000 \mathrm{rpm})$. The obtained cytosol was separated on a 15\% SDS-PAGE and probed for cytochrome $c$, Smac, VDAC and actin as described below. The remaining pellet was lysed in $0.1 \%$ Triton/PBS $\left(15 \mathrm{~min}, 4^{\circ} \mathrm{C}\right)$, centrifuged (14000 r.p.m., $4^{\circ} \mathrm{C}, 10 \mathrm{~min}$ ) and the supernatant containing mitochondrial proteins was analyzed by SDS-PAGE.

Equal amounts of protein were separated by SDS-PAGE and transferred to nitrocellulose membranes (Hybond ${ }^{\mathrm{TM}}-\mathrm{ECL}^{\mathrm{TM}}$, Amersham Biosciences, Freiburg, Germany). Membranes were blocked with $5 \%$ fat-free milk powder in PBS containing $0.05 \%$ Tween-20 (1 h) and incubated with specific antibodies against actin (goat; Santa Cruz), Smac (rabbit; Biozol), Bim, Bcl-2 (Merck Biosciences), calpain (mouse IgG ${ }_{1}$; Chemicon, Hofheim, Germany), ASK, c-jun, phospho-c-jun, cytochrome $c$, caspase-9, JNK, phospho-JNK, VDAC (rabbit or mouse antibodies; Cell Signaling, Frankfurt, Germany), caspase-4 (mouse $\lg \mathrm{G} 1 \kappa$, clone 4B9; MBL), 


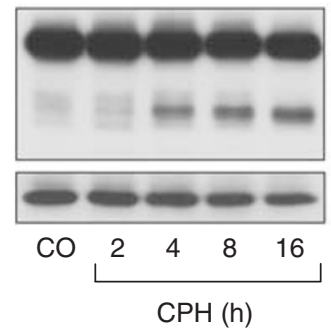

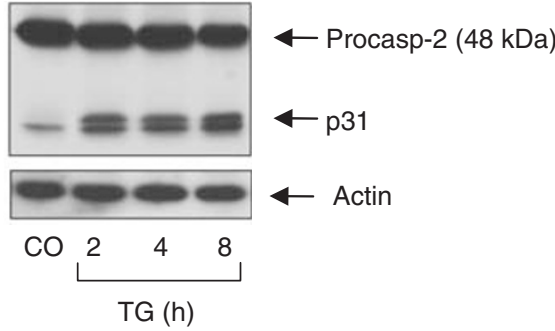

b
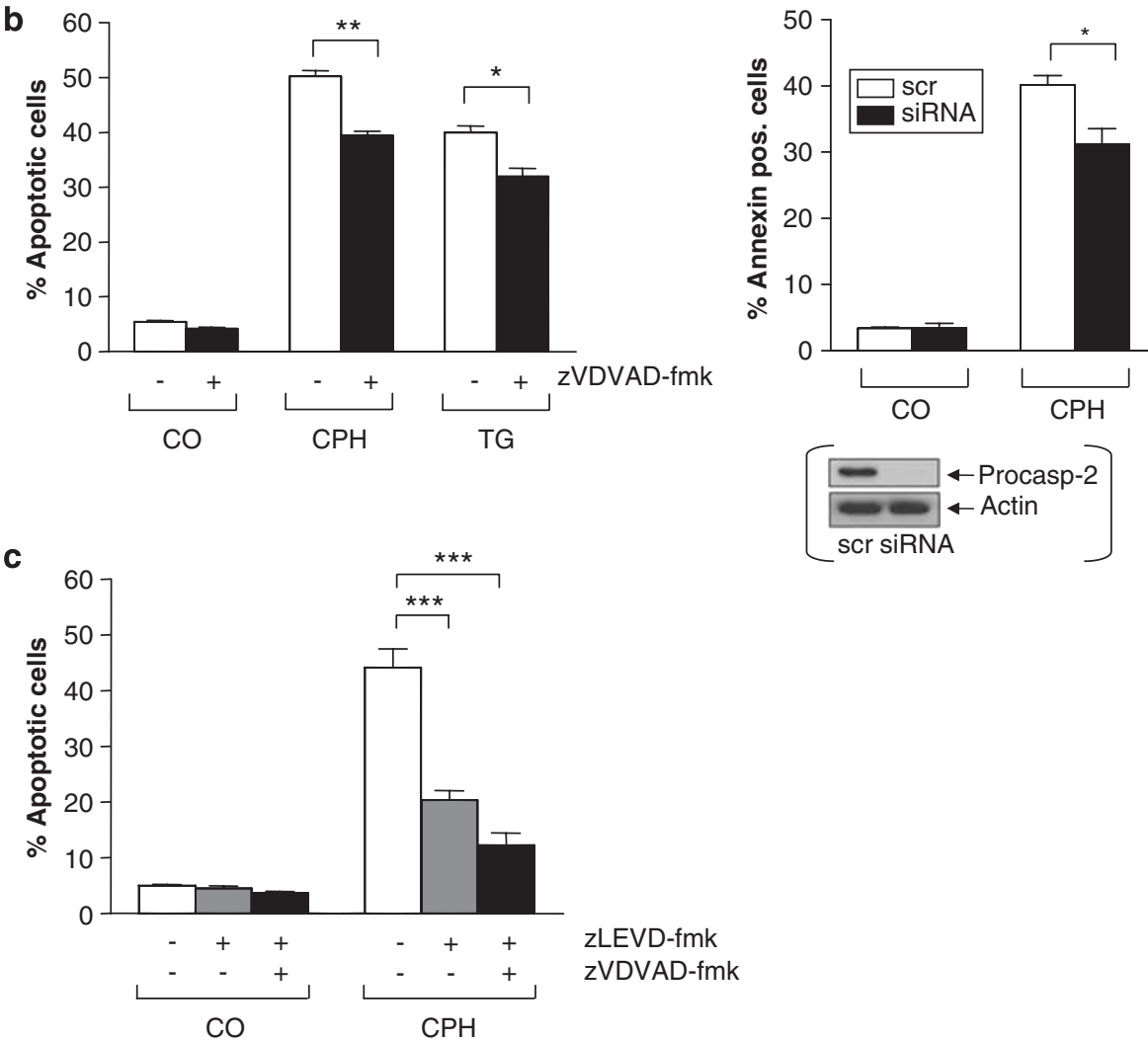

zLEVD-fmk

zVDVAD-fmk

Figure 5 Cephalostatin activates caspase-2. (a) Jurkat cells were either left untreated (CO) or treated with cephalostatin (CPH, $1 \mu \mathrm{M}$ ) or thapsigargin (TG; $3 \mu \mathrm{M})$ for the indicated times. Caspase-2 activation was examined by Western blot. (b) Left panel: Cells were left untreated (CO), or treated with cephalostatin 1 (CPH; $1 \mu \mathrm{M})$ or thapsigargin (TG; $3 \mu \mathrm{M})$ with or without pre-incubation with the caspase-2 inhibitor zVDVAD-fmk $(20 \mu \mathrm{M}, 1 \mathrm{~h})$. Apoptotic cells were quantified by flow cytometry. Right panel: Cells were transfected with either caspase-2 siRNA or scrambled siRNA and left untreated (CO), or treated with cephalostatin 2 (CPH; $50 \mathrm{nM})$. Apoptotic cells were analyzed by annexin staining. Downregulation of caspase-2 was verified by Western blot analysis (see inset). Equal protein loading was controlled by actin. (c) Jurkat cells were left untreated (CO), or treated with cephalostatin $1(\mathrm{CPH} ; 1 \mu \mathrm{M})$ with or without pre-incubation with the caspase-2 inhibitor ZVDVAD-fmk $(20 \mu \mathrm{M}, 1 \mathrm{~h})$ and/or the caspase-4 inhibitor zLEVD-fmk $(20 \mu \mathrm{M}, 1 \mathrm{~h})$. Apoptotic cells were quantified by flow cytometry. Bars, the mean \pm S.E.M. of three independent experiments. ${ }^{*} P<0.05$; ${ }^{* *} P<0.01,{ }^{* \star *} P<0.001$ (unpaired twotailed $t$-test)

RAIDD (mouse IgG1; MBL), PIDD (rabbit; Axxora, Lörrach, Germany), PARP (mouse lgG1; Oncogene, Boston, MA, USA), caspase-3 or caspase-2 (mouse lgG1; BD Transduction Laboratories, Heidelberg, Germany) overnight at $4^{\circ} \mathrm{C}$. Specific proteins were visualized by secondary antibodies conjugated to horseradish peroxidase and the ECL Plus ${ }^{\mathrm{TM}}$ Western Blotting detection reagent (Amersham Biosciences). Membranes were exposed to X-ray film for the appropriate time periods and subsequently developed in a tabletop film processor (Curix 60, Agfa, Cologne, Germany). Equal protein loading was controlled by actin staining.

Immunoprecipitation. Protein A or G sepharose beads (Sigma) were incubated with primary antibody and gently shaken overnight at $4^{\circ} \mathrm{C}$. Cells were treated and collected by centrifugation $\left(10 \mathrm{~min}, 360 \times g, 4^{\circ} \mathrm{C}\right)$, washed with ice-cold PBS and lysed in $1 \%$ Triton X-100, $150 \mathrm{mM} \mathrm{NaCl}, 2 \mathrm{mM}$ EDTA and $30 \mathrm{mM}$ Tris- $\mathrm{HCl}$ (pH 7.5) with the protease inhibitor Complete (Roche) for $30 \mathrm{~min}$. Lysates were centrifuged at $10000 \times \mathrm{g}$ for $10 \mathrm{~min}$ at $4^{\circ} \mathrm{C}$. Equal amounts of protein were added to the antibody beads mixture and incubated for another $3 \mathrm{~h}$ at $4{ }^{\circ} \mathrm{C}$. After centrifugation (14000 r.p.m., $1 \mathrm{~min}, 4^{\circ} \mathrm{C}$ ) probes were washed three times with lysis buffer and separated by SDS-PAGE as described above. For visualization of the proteins, secondary antibody conjugated to horseradish peroxidase or mouse IgG TrueBlot ${ }^{\mathrm{TM}}$ and rabbit lgG TrueBlot (Ebioscience) were used.

Confocal laser scanning microscopy. MCF-7 cells stably expressing either cytochrome $c$-GFP or Smac-YFP were seeded on glass coverslips in 24-well plates. Before $1 \mathrm{~h}$, the end of stimulation cells were stained with Mitotracker Red 580 (Molecular Probes, Karlsruhe, Germany). Cells were washed three times with PBS and fixed with $3 \%$ paraformaldehyde in PBS for $15 \mathrm{~min}$ at room temperature and washed again three times with PBS. Glass coverslips were then covered with a droplet of fluorescent mounting medium and mounted on a microscope slide. Dual-channel images were taken by Zeiss Meta confocal laser scanning microscopy (Jena, Germany). 
a Caspase-9+/+

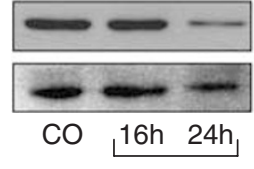

$\mathrm{CPH}$
Caspase-9-/-

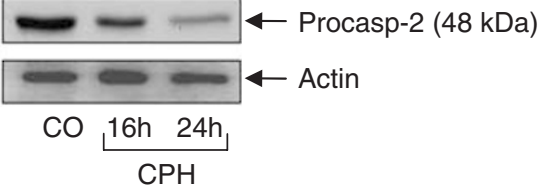

Caspase-2 siRNA

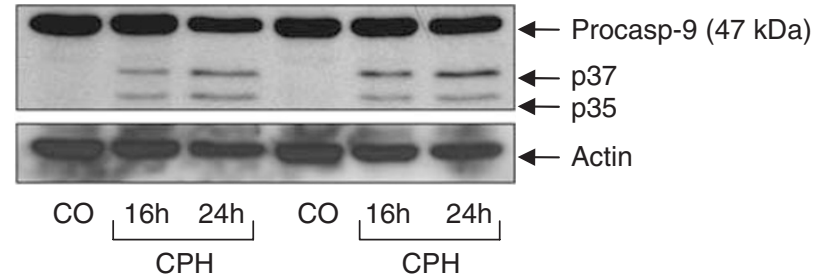

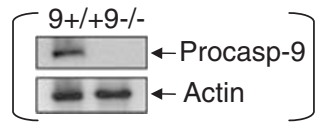

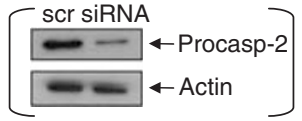

b

IP: PIDD

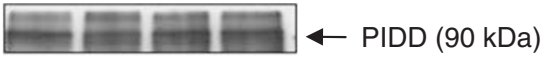

IP: PIDD

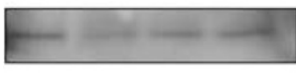

$\longleftarrow \operatorname{RAIDD}(23 \mathrm{kDa})$

IP: PIDD

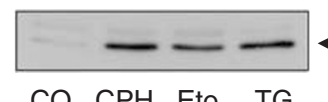

$\leftarrow$ Casp-2 (48 kDa)

IP: Casp.-2

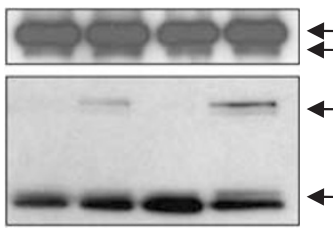

4 Antibody

Casp-2 (48 kDa)

IP: Casp.-2

$\leftarrow$ PIDD $(90 \mathrm{kDa})$

$\mathrm{CO} \mathrm{CPH}$ Eto $\mathrm{TG}$

IP: RAIDD

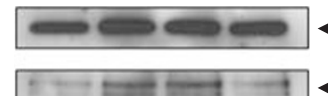

— RAIDD (23 kDa)

IP: RAIDD

CO $\mathrm{CPH}$ TG Eto

C

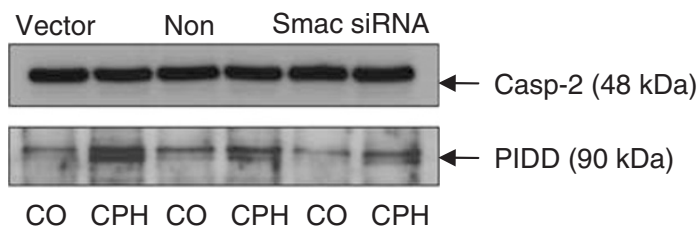

IP: Casp-

IP: Casp-2

$\mathrm{CO} \mathrm{CPH} \mathrm{CO} \mathrm{CPH} \mathrm{CO} \mathrm{CPH}$

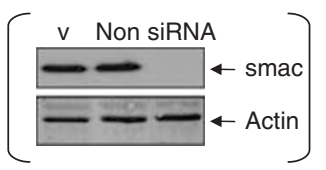

Figure 6 Cephalostatin activates caspase-2 independent of caspase-9 and induces the formation of the PIDDosome. (a) Upper panel: Jurkat cells lacking caspase-9 (Caspase-9-/-) or reconstituted with caspase-9 (Caspase-9+/+) were either left untreated (CO) or treated with cephalostatin (CPH; $1 \mu \mathrm{M})$ for the indicated times. Processing of procaspase-2 was examined by Western blot. Inset shows caspase-9 levels. Lower panel: Jurkat cells were transfected with caspase-2 siRNA or scrambled siRNA and left either untreated $(\mathrm{CO})$ or treated with cephalostatin $2(\mathrm{CPH}, 50 \mathrm{nM})$ for the indicated times. Caspase 9 processing was examined by Western blot. Inset shows caspase-2 downregulation. Equal protein loading was controlled by actin. (b) Jurkat cells were either left untreated (CO) or treated with cephalostatin 2 (CPH; $50 \mathrm{nM})$, thapsigargin (TG; $3 \mu \mathrm{M}$ ) or etoposide (ETO, $2 \mu \mathrm{M}$ ) for $1 \mathrm{~h}$. Caspase-2, PIDD or RAIDD were immunoprecipitated, and caspase-2, PIDD and RAIDD levels were detected by Western blot. Experiments were carried out two times. (c) Jurkat cells were transfected with plasmids endcoding for either smac siRNA, nonsense sequence or vector alone. Cells were either left untreated $(\mathrm{CO})$ or treated with cephalostatin $2(\mathrm{CPH} ; 50 \mathrm{nM})$ for $1 \mathrm{~h}$. Caspase-2 was immunoprecipitated using the TrueBlot system and PIDD and caspase-2 levels were detected by Western blot. Experiment was carried out two times. Smac downregulation was verified by Western Blot (see inset). Equal protein loading was controlled by actin

Smac siRNA. Jurkat cells were transfected by electroporation with the Nucleofector $^{\mathrm{TM}}$ II device (Amaxa, Cologne, Germany) according to the manufacturer's protocol. A total of $4 \times 10^{6}$ Jurkat T cells in exponential growing phase were transfected with $2 \mu \mathrm{g}$ of PSUPER.retro129 and $2 \mu \mathrm{g}$ of
pSUPER.retro1188 (Smac/DIABLO 129: 5'-gatccccgaagcggtgtttctcagaattcaagaga ttctgagaaacaccgcttcttttggaaa-3'; Smac/DIABLO 1188: 5'-gatcccccctgtccagtttgtac gattcaagagaatcgtacaaactggacaggtttttggaaa- $3^{\prime}$ ) in a $1: 1$ mixture of the siRNA constructs. A vector containing a nonsense sequence and the vector alone were 
used as control. Antibiotic selection with $2 \mu \mathrm{g} / \mathrm{ml}$ puromycin was started the day after transfection. Cells were seeded and stimulated on day 4 after nucleofection.

Caspase-2 and Bim siRNA. Sense and antisense siRNA oligonucleotides corresponding to nucleotides $94-114$ of caspase-2 $\left(5^{\prime}\right.$-aaacagctgttgttgagcgaa- $\left.-3^{\prime}\right),{ }^{29}$ Sense and antisense siRNA oligonucleotides of Bim (sense: $5^{\prime}$-caauu gaccuucucgg(dTdT)-3'; antisense: $5^{\prime}$-ccgagaagguagacaauug(dTdT)-3 $\left.3^{\prime}\right)^{40}$ and oligonucleotides corresponding to a scrambled sequence were purchased from Biomers.net $\mathrm{GmbH}$ (Ulm, Germany) and annealed to create the double-stranded siRNAs. Jurkat cells were transfected with $3 \mu \mathrm{g}$ of scrambled or caspase-2 siRNA using the Nucleofector II according to manufacturer's instructions.

Calcium measurement. Changes in intracellular calcium levels can be analyzed with Fura-2-AM. Fura-2 free of $\mathrm{Ca}^{2+}$ emits fluorescence upon excitation at $380 \mathrm{~nm}$, but after binding to $\mathrm{Ca}^{2+}$ fluorescence shifts to $340 \mathrm{~nm}$. Therefore, the $340: 380 \mathrm{~nm}$ ratio of fluorescence intensity provides a parameter for calcium release. Briefly, Jurkat cells were centrifuged $\left(180 \times g, 5 \mathrm{~min}, 23^{\circ} \mathrm{C}\right)$, washed once with Hepes buffer and resuspended at $2 \times 10^{6}$ cells per $\mathrm{ml}$ in Hepes buffer containing $3 \mu \mathrm{M}$ Fura. Cell suspension was incubated for $30 \mathrm{~min}$ at $37^{\circ} \mathrm{C}$; later, a volume of $300 \mu \mathrm{l}$ cell suspension was transferred to an Adhesion Slide (Marienfeldt) and incubated at $37^{\circ} \mathrm{C}$ for further $15 \mathrm{~min}$. After three washing steps with Hepes, cells were stimulated with cephalostatin 2 or thapsigargin for $10 \mathrm{~min}$ and fluorescence was assayed by microscopy (Axiovert 200). Ratio was calculated by TILLVision software.

Statistical analysis. Results are expressed as mean value \pm S.E.M. One-way ANOVA with Bonferroni's post-test and Student's unpaired two-tailed $t$-test were performed using GraphPad Prism version 3.0 for Windows (GraphPad Software, San Diego, CA, USA). $P$-values $<0.05$ were considered significant.

Acknowledgements. We thank Drs Peter $\mathrm{H}$ Krammer and Henning Walczak (German Cancer Research Center, Heidelberg, Germany) for supplying the used Jurkat T-cell clones and Dr Lienhard Schmitz for the ASK1-DN Jurkat cell clone. We thank Bernadette Grohs for the excellent technical assistance. This work was supported by the Deutsche Forschungsgemeinschaft (Vo 376/10-1/2).

1. Dirsch VM, Muller IM, Eichhorst ST, Pettit GR, Kamano Y, Inoue M et al. Cephalostatin 1 selectively triggers the release of Smac/DIABLO and subsequent apoptosis that is characterized by an increased density of the mitochondrial matrix. Cancer Res 2003; 63: 8869-8876.

2. Henderson CJ, Aleo E, Fontanini A, Maestro R, Paroni G, Brancolini C. Caspase activation and apoptosis in response to proteasome inhibitors. Cell Death Differ 2005; 12: 1240-1254

3. Marsden VS, O'Connor L, O'Reilly LA, Silke J, Metcalf D, Ekert PG et al. Apoptosis initiated by Bcl-2-regulated caspase activation independently of the cytochrome $c / A$ paf-1/caspase9 apoptosome. Nature 2002; 419: 634-637.

4. Lopez-Anton N, Rudy A, Barth N, Schmitz ML, Pettit GR, Schulze-Osthoff K et al. The marine product cephalostatin 1 activates an ER stress-specific and apoptosomeindependent apoptotic signaling pathway. J Biol Chem 2006; 281: 33078-33086.

5. Verhagen AM, Ekert PG, Pakusch M, Silke J, Connolly LM, Reid GE et al. Identification of DIABLO, a mammalian protein that promotes apoptosis by binding to and antagonizing IAP proteins. Cell 2000; 102: 43-53.

6. Du C, Fang M, Li Y, Li L, Wang X. Smac, a mitochondrial protein that promotes cytochrome c-dependent caspase activation by eliminating IAP inhibition. Cell 2000; 102: 33-42.

7. Wrzesien-Kus A, Smolewski P, Sobczak-Pluta A, Wierzbowska A, Robak T. The inhibitor of apoptosis protein family and its antagonists in acute leukemias. Apoptosis 2004; 9: 705-715.

8. Cheung HH, Lynn KN, Liston P, Korneluk RG. Involvement of caspase-2 and caspase-9 in endoplasmic reticulum stress-induced apoptosis: a role for the IAPs. Exp Cell Res 2006 312: 2347-2357.

9. Deng $Y$, Ren X, Yang L, Lin Y, Wu X. A JNK-dependent pathway is required for TNFalphainduced apoptosis. Cell 2003; 115: 61-70.

10. Chauhan D, Li G, Hideshima T, Podar K, Mitsiades C, Mltsiades N et al. JNK-dependent release of mitochondrial protein, Smac, during apoptosis in multiple myeloma (MM) cells. J Biol Chem 2003; 278: 17593-17596.

11. Muller IM, Dirsch VM, Rudy A, Lopez-Anton N, Pettit GR, Vollmar AM. Cephalostatin 1 inactivates Bcl-2 by hyperphosphorylation independent of M-phase arrest and DNA damage. Mol Pharmacol 2005; 67: 1684-1689.
12. Altznauer F, Conus S, Cavalli A, Folkers G, Simon HU. Calpain-1 regulates Bax and subsequent Smac-dependent caspase-3 activation in neutrophil apoptosis. J Biol Chem 2004; 279: 5947-5957.

13. Ho PK, Hawkins CJ. Mammalian initiator apoptotic caspases. FEBS J 2005; 272 5436-5453.

14. Lin CF, Chen CL, Chang WT, Jan MS, Hsu LJ, Wu RH et al. Sequential caspase-2 and caspase-8 activation upstream of mitochondria during ceramide and etoposide-induced apoptosis. J Biol Chem 2004; 279: 40755-40761.

15. Dirsch VM, Kirschke SO, Estermeier M, Steffan B, Vollmar AM. Apoptosis signaling triggered by the marine alkaloid ascididemin is routed via caspase-2 and JNK to mitochondria. Oncogene 2004; 23: 1586-1593.

16. O'Reilly LA, Ekert $P$, Harvey N, Marsden V, Cullen L, Vaux DL et al. Caspase-2 is not required for thymocyte or neuronal apoptosis even though cleavage of caspase-2 is dependent on both Apaf-1 and caspase-9. Cell Death Differ 2002; 9: 832-841.

17. Read SH, Baliga BC, Ekert PG, Vaux DL, Kumar S. A novel Apaf-1-independent putative caspase-2 activation complex. J Cell Biol 2002; 159: 739-745.

18. Tinel A, Tschopp J. The PIDDosome, a protein complex implicated in activation of caspase-2 in response to genotoxic stress. Science 2004; 304: 843-846.

19. Green DR. Apoptotic pathways: paper wraps stone blunts scissors. Cell 2000; 102: 1-4.

20. Munoz-Pinedo C, Guio-Carrion A, Goldstein JC, Fitzgerald P, Newmeyer DD, Green DR Different mitochondrial intermembrane space proteins are released during apoptosis in a manner that is coordinately initiated but can vary in duration. Proc Natl Acad Sci USA 2006 103: 11573-11578.

21. Chauhan D, Hideshima T, Rosen S, Reed JC, Kharbanda S, Anderson KC. Apaf-1/ cytochrome $c$-independent and Smac-dependent induction of apoptosis in multiple myeloma (MM) cells. J Biol Chem 2001; 276: 24453-24456.

22. Willis SN, Adams JM. Life in the balance: how BH3-only proteins induce apoptosis. Curr Opin Cell Biol 2005; 17: 617-625.

23. O'Connor L, Strasser A, O'Reilly LA, Hausmann G, Adams JM, Cory S et al. Bim: a novel member of the Bcl-2 family that promotes apoptosis. EMBO J 1998; 17: 384-395.

24. Wood DE, Thomas A, Devi LA, Berman Y, Beavis RC, Reed JC et al. Bax cleavage is mediated by calpain during drug-induced apoptosis. Oncogene 1998; 17 1069-1078.

25. Salvesen GS, Duckett CS. IAP proteins: blocking the road to death's door. Nat Rev Mol Cell Biol 2002; 3: 401-410.

26. Vaux DL, Silke J. IAPs, RINGs and ubiquitylation. Nat Rev Mol Cell Biol 2005; 6: 287-297.

27. Vogler M, Giagkousiklidis S, Genze F, Gschwend JE, Debatin KM, Fulda S. Inhibition of clonogenic tumor growth: a novel function of Smac contributing to its antitumor activity. Oncogene 2005; 24: 7190-7202.

28. Giagkousiklidis S, Vogler M, Westhoff MA, Kasperczyk H, Debatin KM, Fulda S Sensitization for gamma-irradiation-induced apoptosis by second mitochondria-derived activator of caspase. Cancer Res 2005; 65: 10502-10513.

29. Lassus $P$, Opitz-Araya X, Lazebnik Y. Requirement for caspase-2 in stress-induced apoptosis before mitochondrial permeabilization. Science 2002; 297: 1352-1354.

30. Mancini M, Machamer CE, Roy S, Nicholson DW, Thornberry NA, Casciola-Rosen LA et al. Caspase-2 is localized at the Golgi complex and cleaves golgin-160 during apoptosis. J Cell Biol 2000; 149: 603-612.

31. Talanian RV, Quinlan C, Trautz S, Hackett MC, Mankovich JA, Banach D et al. Substrate specificities of caspase family proteases. J Biol Chem 1997; 272: 9677-9682.

32. Zhivotovsky B, Orrenius S. Caspase-2 function in response to DNA damage. Biochem Biophys Res Commun 2005; 331: 859-867.

33. Troy CM, Rabacchi SA, Hohl JB, Angelastro JM, Greene LA, Shelanski ML. Death in the balance: alternative participation of the caspase-2 and -9 pathways in neuronal death induced by nerve growth factor deprivation. J Neurosci 2001; 21: 5007-5016.

34. Wang Q, Maniati M, Jabado O, Pavlaki M, Troy CM, Greene LA et al. RAIDD is required for apoptosis of PC12 cells and sympathetic neurons induced by trophic factor withdrawal. Cell Death Differ 2006; 13: 75-83.

35. Wagner KW, Engels IH, Deveraux QL. Caspase-2 can function upstream of bid cleavage in the TRAIL apoptosis pathway. J Biol Chem 2004; 279: 35047-35052.

36. Troy CM, Rabacchi SA, Friedman WJ, Frappier TF, Brown K, Shelanski ML. Caspase-2 mediates neuronal cell death induced by beta-amyloid. J Neurosci 2000; 20: 1386-1392.

37. Vakifahmetoglu H, Olsson M, Orrenius S, Zhivotovsky B. Functional connection between p53 and caspase-2 is essential for apoptosis induced by DNA damage. Oncogene 2006; 25: 5683-5692.

38. Taghiyev AF, Guseva NV, Glover RA, Rokhlin OW, Cohen MB. TSA-induced cell death in prostate cancer cell lines is caspase-2 dependent and involves the PIDDosome. Cancer Biol Ther 2006; 5: 1199-1205.

39. Gil-Parrado S, Assfalg-Machleidt I, Fiorino F, Deluca D, Pfeiler D, Schaschke N et al Calpastatin exon 1B-derived peptide, a selective inhibitor of calpain: enhancing cell permeability by conjugation with penetratin. Biol Chem 2003; 384: 395-402.

40. Sunters A, Fernández de Mattos S, Stahl M, Brosens JJ, Zoumpoulidou G, Saunders CA et al. FoxO3a transcriptional regulation of Bim controls apoptosis in paclitaxel-treated breast cancer cell lines. J Biol Chem 2003; 278: 49795-49805. 